\title{
THE DEVELOPMENT OF INSTRUMENT TO ASSESS STUDENTS' AFFECTIVE BASED ON SCIENTIFIC APPROACH IN ENGLISH AS A FOREIGN LANGUAGE (EFL) CLASSROOM
}

\author{
Ira Maisarah $^{1^{*}}$, Noermanzah ${ }^{2}$, Safnil Arsyad ${ }^{3}$, M. Zaim ${ }^{4}$, Dian Eka Chandra Wardhana ${ }^{5}$ \\ $1^{*}, 2,3,5$ Department of Language and Arts Education, University of Bengkulu, Indonesia; ${ }^{4}$ Faculty of Language and Arts, \\ Padang State University, West Sumatera, Indonesia. \\ Email: ${ }^{1 *}$ iramaisarah@unib.ac.id, ${ }_{5}^{2}$ noermanzah@unib.ac.id, ${ }^{3}$ safnil@unib.ac.id, ${ }^{4}$ mzaim_unp@yahoo.com, \\ 5 dec.wardhana@unib.ac.id@unib.ac.id
}

Article History: Received on $14^{\text {th }}$ June 2020, Revised on $12^{\text {th }}$ August 2020, Published on $27^{\text {th }}$ August 2020

\begin{abstract}
Purpose of the study: The objective of this research was to explain the results of the development of instruments to assess the students' affective based on scientific approaches in the EFL class.
\end{abstract}

Methodology: This study used the ADDIE method that consists of five steps: (1) analyzing, (2) designing, (3) developing, (4) implementing, and (5) evaluating. There were some instruments of the research used to gather the data such as the expert's validation sheet and questionnaire. Statistical analyses used in this research were Alpha Cronbach, the test of normality Kolmogorov-Smirnov, the test of homogeneity Levene, the test of linearity, the test of correlational Pearson, test of regression, and Wilcoxon test.

Main Findings: The result showed that the development of an instrument to evaluate students' affective based on scientific approach was considered by some items, e.g. phases in scientific approach, skills in English language teaching, learning experiences, affective aspects, and indicator of assessment. Finally, it can be stated that (1) the instrument was valid with the mean Score in rank between 1-124 is 114.8; (2) the instrument reliable with the Score is 0.754; (3) the instrument was tested with the Asymp. Sig score of 0.042 .

Applications of this study: This study proved that the instrument of affective assessment was valid, practice, and effective to be used by the English teachers in assessing the students' affective during the teaching and learning process at the EFL classroom.

Novelty/Originality of this study: The success of a student is not only measured based on the cognitive aspect but also based on the affective aspect.

Keywords: Development, Instrument, Affective, Scientific Approach, EFL Classroom.

\section{INTRODUCTION}

Human being has three characteristics, namely, cognitive, affective, and psychomotor (Anderson \& Bourke, 2013). The three abilities possessed by humans must be developed by the teacher to produce graduates who are creative, think critically, collaboratively, and can work together (Karto et al., 2019; Noermanzah \& Friantary, 2019). Every single characteristic will be a different one from another due to the input that was given by someone (Fazeli, 2011). In other words, it can be said that a better input will give a better output. It means that a teacher is not only has a responsibility to transfer the knowledge but also has a responsibility to educate the affective of the students.

That is why assessing the output of learning, e.g. knowledge, affective, and skills are very needed to be done by teachers. As stated by Nitko (2001), assessment is a step to collect the information to decide whether the students can reach the learning objective or not. Assessment is the way to collect the data of students in learning (Brown, 2003). It is a longitudinal process. To reach that purpose, the teachers can see the way the students give a response in their class.

Assessing the cognitive domain is not as difficult as assessing the affective domain. To assess the students' competence in the cognitive domain, a teacher can give a formative or summative assessment (Bloom, et al., 1964). Then, the teacher directly can decide that whether the students have good or bad competence in that subject. Since 1962, some experts of education realized that the affective domain significantly influences learning (Bloom, et al., 1981). Then, Octova, et. al (2014) argued that affective competence influences cognitive competence. This is because cognitive competence has a structure for keeping records of various things and applying them when needed in affective activities (Bloom, in Turi, et al. 2018).

Previous studies on affective assessment have shown that the affective skill significantly affects learning such as motivation to read (Givens, 2010), motivation to do something (Keblowska, 2012), and develop communicative competence (Piasecka, 2013). These findings revealed that the affective domain can increase learning the outcome since the students use their emotions and feeling for learning. Affective is multi-dimensional to construct the students' awareness of learning.

In carrying out this research, some previous researchers have done some studies that were related to the development of practical assessment. Givens (2010) developed the affective assessment to identify the students who love to read and do not love to read, Farisi (2012) and Rimland (2013) developed an effective assessment device for self-assessment, $\underline{\text { Rani, }}$ 
et. al. (2010) developed a peer-assessment instrument in assessing students' affective for the physic subject, Nufus, et. al. (2017) developed an instrument based on curriculum 2013 in chemistry subject to assess the students' affective, and Wicaksono et. al. (2016) developed an effective assessment for observation technique, self-assessment, and peerassessment at thematic learning in elementary school. The findings of these studies suggested that the affective assessment can improve the students' positive attitude during teaching and learning processes. In this case, the students felt that every single attitude that was showed by themselves would be noted by teachers. So, they have to be good students to have a good record of their affective domain. But, none of these studies focused on English language learning.

Most of these studies developed an instrument of affective assessment in science and thematic subject. In other words, there was no one previous study that has a focus on the designing of an instrument to assess the students' affective, especially when it is related to the approach used by teachers in teaching. Assessing the affective domain was separated from the teaching and learning process. Moreover, these studies were only focused on the process of effective assessment in pre and post-teaching. The assessment of affective domain must be done in three parts of teaching that is pre, ongoing, and post-teaching (Pham, 2015).

Afterward, since the affective domain has received much attention from some experts in education, the Indonesian government put the affective domain like the main point in deciding for the students' rank. According to Sudirman (2019), effective is also called a character which is mean the attitude that showed by someone as the reflection of his/her behavior. Besides, Gray (2010) as quoted in Sudirman (2019) describes the character as a term of some values. This is in line with the goals of national education as stated in Undang-Undang Number 20 of 2003 that the future generations must have self-control, noble character, good personality, and spiritual power (Feist \& Feist, 2006). Therefore, the Indonesian government launched the 2013 curriculum to answer the challenge by giving a scientific approach as the approach of learning in the classroom. The changes in the curriculum are also a way to give a response to the changes in society (Zaim, 2017). According to the regulation from Kemdikbud in 2014, the scientific approach can help the teachers to reach the learning outcome (Zaim, 2017).

Besides, the effective development of each learner must be known by every teacher who taught in elementary and secondary school. It is also realized that curriculum changes result in changes to each component in that curriculum, including the assessment. To assess how good or bad the students' affective, the teacher can be implementing or using an effective instrument to control the students' attitudes. So, every teacher, including English teachers has a responsibility to design every assessment, e.g. effective assessment. Assessing effective in English language teaching is not easy work. The English teachers must be able to make a connection between the process of learning and the aspect of affective that will be assessed. Related to the results of preliminary studies that were done by Julia \& Supriyadi (2018), teachers in schools have no design in applying effective in the English as Foreign Language (EFL) classroom.

Furthermore, since 2013, for all subject matters, the teachers must use curriculum 2013 as the new one to reach the goals of learning. Muttaqin, et al. (2018) view that curriculum 2013 reinforces the students to have good motivation and potential in learning. Besides, English teachers must also consider the phases of the scientific approach that are used in the EFL classroom. In line with the teachers' responsibilities in assessing the students' affective, they must be able to develop an appropriate instrument for affective assessment (Krathwohl et al., 1974). As has been researched by Maisarah, et al. (2018), it's found that simple and comprehensive are need to evaluate the students' attitude in the EFL classroom by teachers. They need an instrument for the EFL classroom process. In this case, they were not able yet in designing an instrument to assess effective for the ongoing process of teaching, especially if the approaches of learning must be involved in that instrument (Maisarah et al., 2018).

In this paper, we demonstrate the result of the development instrument to assess effective based on the scientific approach in the EFL classroom. The focus was on the development of an observation sheet used by English teachers. Why was it so? Brown (2003) explained that affective assessment can be categorized into an alternative assessment. There are some types of affective assessments such as observation sheet, journal, self-assessment, peer-assessment, and interview. Kemdikbud (2015) suggested that the observation sheet is the main assessment that must be used by teachers to assess the students' affective. McCoach, et. al. (2013) also said that direct observation is popular to be used in collecting the data. Furthermore, Walter (2000) in Koc (2013) viewed that observation that is done by teachers in the classroom can be used to control the students' motivation and other attitudes.

Finally, to scope the explanation of the paper, we present a research question: "how are the validity, reliability, practicality, and effectivity of the product instrument that can be used to measure or assess the students' affective based on the scientific approach in EFL classroom?"

Based on the research question, the objectives of the study were to find out and prove the validity, reliability, practicality, and effectiveness of the instrument for affective assessment based on the scientific approach in the EFL classroom. Those objectives were also answered by using some hypotheses. 


\section{METHODOLOGY}

\section{Research Design}

This research used the ADDIE method (Branch, 2009). ADDIE is believed to be a comprehensive method for developing a product. It has five phases: (1) analyzing, (2) designing, (3) developing, (4) implementing, and (5) evaluating. The method of the research is clearly explained as follows:

\section{Respondents}

There were five experts as a validator for this instrument. These experts have different fields such as experts in assessment, psychology, English language teaching, Indonesian language, and design of learning. These experts came from different universities in Indonesia. Then, there were five English teachers to become the informant of this research. They all were English teachers whose teaching at seventh-grade students and used a scientific approach in their teaching.

\section{Instruments}

There were some instruments of the research used to gather the data such as the expert's validation sheet, and questionnaire. These instruments were used to find out the validity, reliability, practicality, and effectivity of the instrument to assess the students' affective based on a scientific approach.

\section{Procedures}

There were five procedures used in this research, as suggested by Branch (2009) in the ADDIE model. The first stage is the analysis. In the analysis stage, it was needed to analyze the teachers' needs related to the instrument for affective assessment that would be developed in this research. Design means that the content or form of the instrument for affective assessment which would be created. The third stage is the development. That is the way how the instrument for affective assessment can be said valid by taking some experts' judgment. The fourth stage is implementation. Its function was to know the reliability and practicality. Finally, the fifth stage is the evaluation. The importance of the evaluation was to revise it.

\section{Data Analysis}

The data were analyzed using a qualitative and quantitative approach. A qualitative approach is used to reduce the data, to display the data, and to verify the data. Then, for quantitative data, there are some statistical analyses formulas used such as Alpha Cronbach, the test of normality Kolmogorov-Smirnov, the test of homogeneity Levene, the test of linearity, the test of correlational Pearson, test of regression, and Wilcoxon test. For the following measurement, tools were applied:

1. Indicator of experts' validation sheet for the instrument of affective assessment

Table 1: Indicator of validation sheet for the instrument to assess the students' affective based on the scientific approach

\begin{tabular}{llll}
\hline Indicator & Sub Indicator & Total of Item & Number of Questions \\
\hline Content & Correct and detail & 11 & $\begin{array}{l}1 \mathrm{a}, 1 \mathrm{~b}, 1 \mathrm{c}, 1 \mathrm{~d}, 1 \mathrm{e}, 1 \mathrm{f}, 1 \mathrm{~g}, 1 \mathrm{~h}, 1 \mathrm{i}, \\
1 \mathrm{k}, 1 \mathrm{k}\end{array}$ \\
\hline \multirow{2}{*}{ Language } & $\begin{array}{l}\text { Clear and appropriate with } \\
\text { the rules of the Indonesian } \\
\text { language }\end{array}$ & 11 & $\begin{array}{l}2 \mathrm{a}, 2 \mathrm{~b}, 2 \mathrm{c}, 2 \mathrm{~d}, 2 \mathrm{e}, 2 \mathrm{f}, 2 \mathrm{~g}, 2 \mathrm{~h}, 2 \mathrm{i}, \\
2 \mathrm{j}, 2 \mathrm{k}\end{array}$ \\
\hline Layout & Content Structure & 2 & $3 \mathrm{a}, 3 \mathrm{~b}$ \\
\hline \multirow{3}{*}{ Graphic } & $\mathrm{a}$ Cover design & 4 & $4 \mathrm{a}(\mathrm{a}), 4 \mathrm{a}(\mathrm{b}), 4 \mathrm{a}(\mathrm{c}), 4 \mathrm{a}(\mathrm{d})$ \\
\cline { 2 - 4 } & b. Content layout & 3 & $\begin{array}{l}4 \mathrm{~b}(\mathrm{a}), 4 \mathrm{~b}(\mathrm{~b}), \\
4 \mathrm{~b}(\mathrm{c})\end{array}$ \\
\hline
\end{tabular}

Source: (Modified from: Atmazaki, 2013)

2. Analysis of experts' validation sheet for the instrument of affective assessment

Table 2: Indicator of validation sheet for the instrument to assess the students' affective based on the scientific approach

\begin{tabular}{ll}
\hline Score & Category \\
\hline $31-53$ & Not valid /Can not be used \\
\hline $54-76$ & Valid enough/Can be used with much revision \\
\hline $77-99$ & Valid/Can be used with a few revision \\
\hline $100-124$ & Very valid/Can be used without revision \\
\hline
\end{tabular}

Source: $\underline{\text { (Modified from Riduwan, 2015) }}$ 


\section{RESULTS}

The development process has specified as follows:

1. The affective instrument was based on spiritual and social competences,

2. The affective instrument was developed for six basic competences of English language learning,

3. The affective instrument was developed for each topic of basic competences,

4. The affective instrument was developed by considering affective aspects,

5. The affective instrument was developed for all language skills i.e. listening, speaking, reading, and writing,

6. The affective instrument affective has a general description such as basic competence, time of learning, and identity of school, class, and English teachers,

7. Content of the affective instrument was divided into: (1) five phases of scientific approach i.e. observing, questioning, experimenting, associating, and communicating, (2) component of affective aspects, (3) column for students' name, (4) column for indicator, (5) column for an average score of individual and classical, (6) and teachers' signature,

8. Every affective aspect was spread in every phase of the scientific approach,

9. The affective instrument was completed with the recapitulation sheet,

10. The affective instrument has its rubric scoring within the score 1-4,

11. The affective instrument has a syntax for using this model,

12. The affective instrument was designed in a good arrangement,

13. The cover of the instrument product was designed full color.

Furthermore, to answer the research question as mentioned in the previous explanation, the findings of the research are divided into four points. First, experts' validation. Second, the reliability of the product of affective instrument. Third, the practicality of the product of affective instrument. Finally, the effectivity the product of affective instrument.

\section{Experts' Validation of Instrument for Affective Assessment based on Scientific Approach}

As mentioned in the previous explanation, five experts validated the the product of affective instrument. These experts gave a score for all of the indicators that were stated in the validation sheet. The result of the validation can be seen in the following figure:

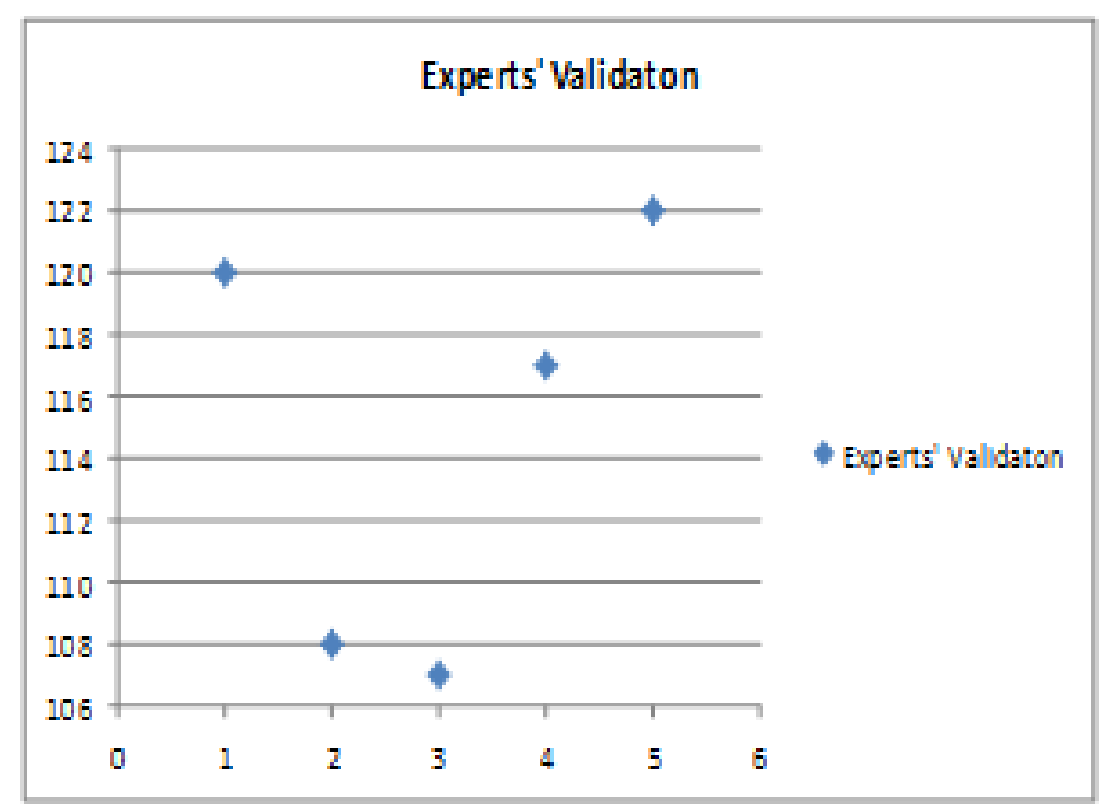

(V1=Validator 1, V2=Validator 2, V3=Validator 3, V4=Validator 4, and V5=Validator 5)

Figure 1: The result of experts' validation to assess the students' affective based on the scientific approach

Figure 1 presents the total Score of validation for each validator was different. The Total Score from the first validator was 120 , the second validator was 108 , the third validator was 107 , the fourth validator was 117 , and the fifth validator was 122 . So, based on these scores, it can be concluded that the instrument for affective assessment was very valid and can be used without any revision. But, the validators suggested the aspect of the graphic. The graphic of the product of 
affective instrument needs a revision. The graphic itself includes design, illustration, color, and layout of the cover. In other words, the cover of the instrument for affective assessment needs to be changed more colorful and interesting.

In the beginning, the cover of the product of effective instrument was opaque. Besides, the illustration used was not describing the component of effective. The layout of the cover was monotonous. Then, in the process of revision, the cover of the affective instrument was sharper and brighter. Also, the effective components such as religious attitude, honest, responsible, discipline, hard-work, self-confident, logical thinking, critical thinking, creative thinking, innovative thinking, independent, curious, love science, respect, polite, democratic, emotionally intelligent, and pluralist stated in the cover. The following figure is the final cover of the instrument for effective assessment.

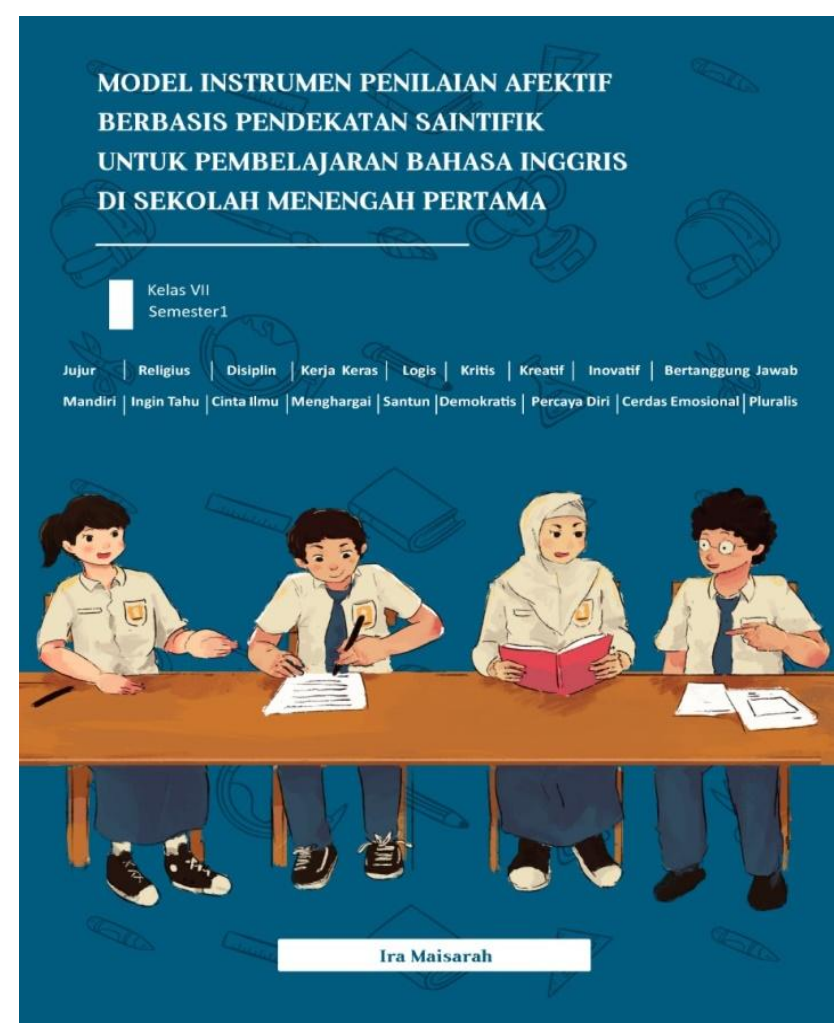

Figure 2: Cover of the product of affective instrument

Figure 2 shows the color of the cover is dark blue with a little sharper and brighter. The dark blue color is representative of color for students' uniform at Junior High School in Indonesia. Then, on the cover, there are some components i.e. the title of the instrument for affective assessment, grade, semester, some aspects of affective, and caricature. The caricature is used to show the activities that usually done in the learning process such as writing and discussing with a classmate.

\section{Reliability of Instrument to Assess the Students' Affective based on Scientific Approach}

This instrument for affective assessment has its characteristics. For example, every phase in the scientific approach has different affective to be assessed. First, in the observing phase, four types of affective will be assessed, such as religious, curiosity, logical thinking, and love knowledge. Second, in the questioning phase, four types of affective will be assessed such as religious, politeness, critical thinking, and self-confidence (Syarif, 2014). Third, in the experimenting phase, seven types of affective will be assessed such as religious, politeness, respect, self-confidence, honesty, hard work, and independence. Fourth, in the associating phase, four types of affective will be assessed, such as religious, logical thinking, responsible, and discipline. Fifth, in the communicating phase, six types of affective will be assessed such as religious, democracy, pluralist, emotional intelligence, innovative, and creative.

The reliability score of the product of instrument was gotten from the implementation of the pilot project for that instrument at two schools as the research samples. One purpose of this pilot project was to know the consistency of English teachers in giving the affective Score for each student by using this instrument. In this case, the reliability test was taken in one part only, because it has the same form and way in filling the instrument for affective assessment. The English teacher only needs to write the Score from 1 until 4 for each aspect of affective.

Besides, the data was taken from the phase of observing. The learning activity was the students paid attention to the text or picture that was given by English teachers seriously. The following table is the result of the reliability test by using Split-Half. 
Table 3: Statistic test for the reliability of an instrument to assess the students' affective based on the scientific approach

\begin{tabular}{|c|c|c|c|}
\hline \multicolumn{4}{|l|}{ Reliability Statistics } \\
\hline \multirow{5}{*}{ Cronbach's Alpha } & \multirow{2}{*}{ Part 1} & Value & .708 \\
\hline & & $\mathrm{N}$ of Items & $3^{\mathrm{a}}$ \\
\hline & \multirow{2}{*}{ Part 2} & Value & .762 \\
\hline & & $\mathrm{N}$ of Items & $3^{b}$ \\
\hline & Total N of Items & & 6 \\
\hline $\begin{array}{l}\text { Correlation Between } \\
\text { Forms }\end{array}$ & & & .605 \\
\hline \multirow{2}{*}{$\begin{array}{l}\text { Spearman-Brown } \\
\text { Coefficient }\end{array}$} & $\begin{array}{l}\text { Equal } \\
\text { Length }\end{array}$ & & .754 \\
\hline & $\begin{array}{l}\text { Unequal } \\
\text { Length }\end{array}$ & & .754 \\
\hline $\begin{array}{l}\text { Guttman split-half } \\
\text { Coefficient }\end{array}$ & & & .752 \\
\hline
\end{tabular}

a. The items are Score for religious 1, Score for religious 2, Score for religious 3.

b. The items are Score for respect, Score for curiosity, Score for hard-work.

Table 3 shows the correlation between all items as seen in coefficient correlation Spearman-Brown that consists of equal and unequal length with the Score for each item is 0.754. Then, the coefficient correlation Gutman Split-Half with the Score is 0.752 . Next, the highest Score of coefficient correlation between items in Cronbach's Alpha, Spearman-Brown, and Gutman Split-Half with the scores for all items is $0.605,0.754$, and 0.752. It indicates the highest reliability. Finally, the result proves that affective assessment is reliable to be used massively.

\section{The practicality of Instrument to Assess the Students' Affective based on Scientific Approach}

Two types of questionnaires were used to find out practicality. First, a questionnaire that was used to measure the practicality of instruments to assess the students' affective based on a scientific approach. Second, a questionnaire that was used to measure the practicality of affective instruments from Kemdikbud (2015). Every questionnaire consists of 18 questions with five choices in like scale i.e. 5 (strongly agree), 4 (agree), 3 (somewhat agree), 2 (slightly agree), and 1 (not agree). Then, these questionnaires were given to five English teachers. To test the practicality, two hypotheses must be proven. It can be seen as follow:

Ho: The instrument for affective assessment does not practice in EFL classroom.

Ha: The instrument for affective assessment is practice in EFL classroom.

In this session, five English teachers who were the participants of this research must fill the questionnaire. They were free to give the Score in that questionnaire based on their experience in using the product of affective instrument. The example of an instrument that has been developed can be seen as follow:

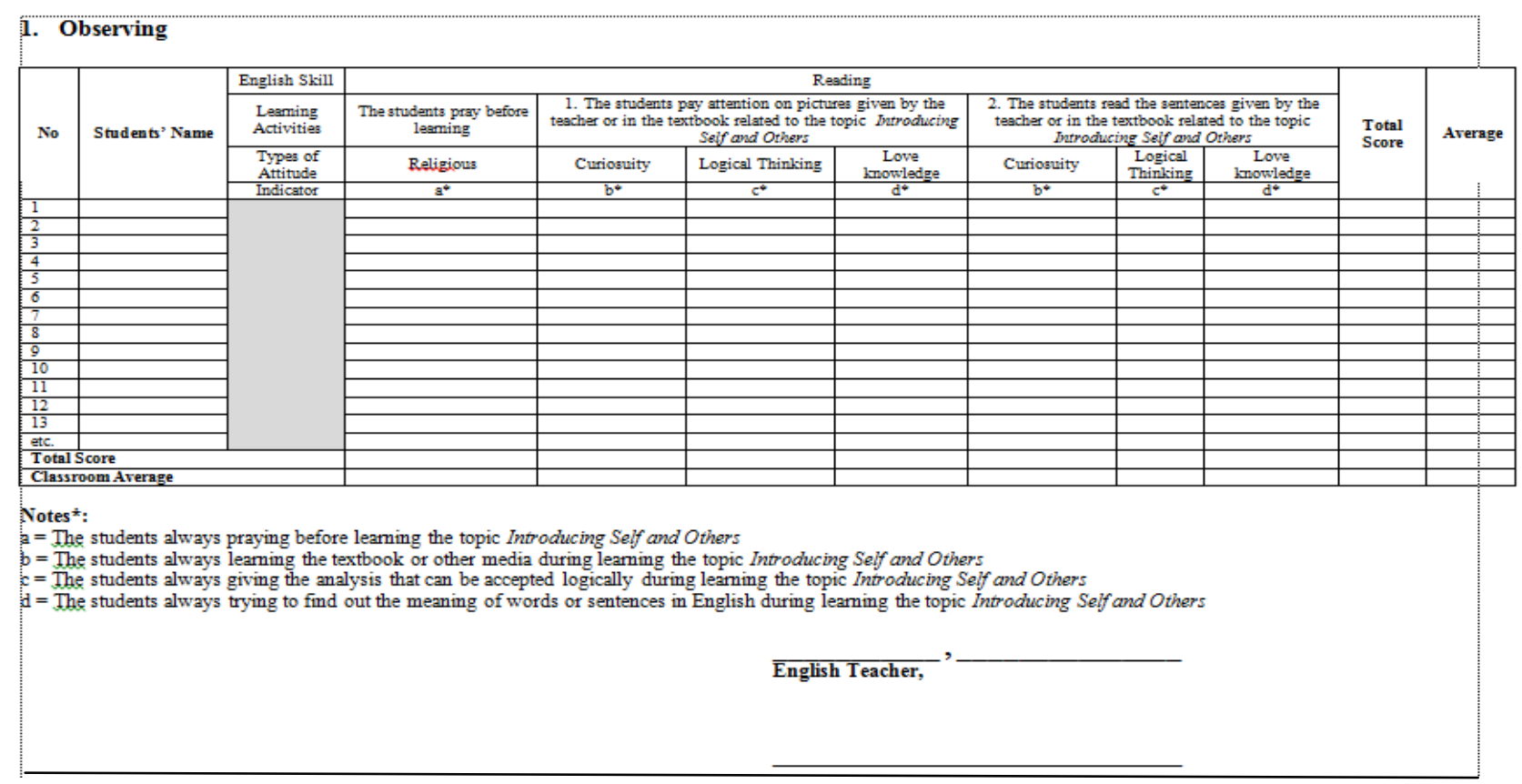

Figure 3: The instrument to assess students' affective based on the scientific approach 
Figure 3 describes an instrument for affective assessment that consists of some columns. Every column has its description such as a column for number, name of students, the orientation of English language skills, some learning activities, affective aspects, indicator, total Score, and the average Score for individual and classical. Then, at the bottom of the observation sheet, there is a space for the English teacher's signature. The numerical in the response cells of the column indicates the points assigned to each teacher's answering in giving scoring.

So, to prove the hypothesis for practicality, we used Wilcoxon-Test, because the data were not normally distributed. The result of the practicality test is described in table 4 :

Table 4: Wilcoxon test for practicality

\begin{tabular}{ll}
\hline Test Statistics & \multicolumn{1}{l}{$\begin{array}{l}\text { The Score of Teachers' Perception for Practicality Test of the Instrument to Assess the } \\
\text { Students' Affective based on Scientific Approach - Score of Teachers' Perception for } \\
\text { Practicality Test of Affective Assessment from Kemdikbud }\end{array}$} \\
\hline Z & $-2.032^{\text {b }}$ \\
\hline $\begin{array}{l}\text { Asymp. Sig. } \\
\text { (2-tailed) }\end{array}$ & .042 \\
\hline a. Wilcoxon Signed Ranks Test \\
\hline b. Based on negative ranks.
\end{tabular}

Table 4 shows that the Score of Asymp.sig. (2-tailed) $=0.042$. So, if the sig value is greater than 0.05 , then Ho is accepted. The Score for Asymp.sig. (2-tailed) $=0.042$ is smaller than 0.05. It means that Ho is rejected, and Ha is accepted. Finally, it can be concluded the instrument for affective assessment is practice in the EFL classroom. This is also proved by the improvement of the average Score for teachers' perception. There is an improvement as much as 10.20 points from 68.60 up to 78.80 .

\section{Effectivity of Instrument to Assess the Students' Affective based on Scientific Approach}

To test the product effectiveness of affective instrument, the researcher gave a questionnaire to the English teachers. There are also two types of questionnaires that were used to find out effectivity. First, a questionnaire that was used to measure the effectivity of the instrument. Second, a questionnaire that was used to measure the effectivity of affective instruments from Kemdikbud (2015). Every questionnaire consists of 21 questions with five choices on a Likert scale i.e. 5 (strongly agree), 4 (agree), 3 (somewhat agree), 2 (slightly agree), and 1 (not agree). Then, these questionnaires were also given to five English teachers who taught at VII grade in Junior High Schools in Merangin Sub-District.

Table 5: Wilcoxon test for effectivity

\begin{tabular}{ll}
\hline Test Statistics & \\
\hline & $\begin{array}{l}\text { The Score of Teachers' Perception for Effectivity Test of the Instrument to assess the students' } \\
\text { affective based on Scientific Approach - Score of Teachers' Perception for Effectivity Test of } \\
\text { Affective Assessment from Kemdikbud }\end{array}$ \\
\hline $\mathrm{Z}$ & $-2.032^{\mathrm{b}}$ \\
\hline $\begin{array}{l}\text { Asymp. Sig. } \\
\text { (2-tailed) }\end{array}$ & .042 \\
\hline a. Wilcoxon Signed Ranks Test \\
\hline b. Based on negative ranks.
\end{tabular}

Table 5 shows that the Score of Asymp.sig. (2-tailed) $=0.042$. So, if the sig value is greater than 0.05 , then Ho is accepted. The Score for Asymp.sig. (2-tailed) $=0.042$ is smaller than 0.05. It means that Ho is rejected, and Ha is accepted. Finally, it can be concluded that the product of affective instrument is effective used in the EFL classroom. This is also proved by the improvement of the average Score for teachers' perception. There is an improvement as much as 7.60 points from 84.00 up to 91.60 .

The present study has four main findings. First, the validity of the product of affective instrument. Second, the reliability of the product of affective instrument. Third, the practicality of the product of affective instrument. Fourth, the effectivity of the product of affective instrument. Based on thus components, the novelty of the product of the instrument as follows:

Table 6: The novelty of the product of affective instrument

\begin{tabular}{ll}
\hline Components & Descriptions \\
\hline Affective & Affective assessment up to characterization level \\
\hline Scientific & Affective assessment details for each phase of the scientific approach \\
\hline
\end{tabular}




\begin{tabular}{|c|c|}
\hline Approach & \\
\hline \multirow{2}{*}{$\begin{array}{l}\text { Affective } \\
\text { Assessment } \\
\text { Technique }\end{array}$} & 1. Assessment Format for observation sheet is detail \\
\hline & 2. There is an indicator of affective aspect \\
\hline \multirow{3}{*}{$\begin{array}{l}\text { English Language } \\
\text { Learning }\end{array}$} & 1. Affective assessment for each topic \\
\hline & 2. Learning activities are described in detail \\
\hline & 3. English language skills were noted for each phase of the scientific approach \\
\hline \multirow{2}{*}{ Affective Aspects } & 1. 12 affective aspects must be assessed by English teachers \\
\hline & 2. There is an additional of pluralist aspect \\
\hline
\end{tabular}

\section{DISCUSSION}

The instrument can already be used as a medium or an attempt by English teachers to assess the attitude of the EFL classroom. Because, by using this instrument, learners feel more controlled and feel cared for by the teacher. With these controls, students are expected to be consistent with the positive attitudes they have. This is similar to the results of research conducted by Palk (2018) and Markle \& O'Banion (2014) that a teacher needs to form a positive attitude toward the students. So, this model is one way to control a positive attitude. In this instrument, the English teachers could see the detail of affective showed by the students during the teaching and learning process. The English teachers paid attention to the body language and the words or sentences that were produced by the students. The positive attitude was noted as the best progress during the learning process, while the negative attitude was needed to be solved by the English teachers. It is very useful to be done to enrich the whole aspects of meaningful human beings.

Based on findings, the development product of affective instrument has been validated by some experts and shows a positive result, which is very valid. This suggests that the product of affective instrument is relevant to the ideal concept of an affective instrument. The ideal concept is the assessment column and the detailed columns as a description of the affective assessment. That is, this validation process has been done correctly as Sugiyono (2017) said that validation aims to test product effectiveness. Without validation from some experts, there was no justification to prove that the instrument of affective assessment can be used by the English teachers in assessing the students' affective. The functions of this validation were to justify the structure of the instrument that has been constructed during this study, the language used in this instrument, and also the way how to make this instrument to be more understandable by the English teachers (Ali, 2017; Li \& Luo, 2019).

The results of reliability, practicality, and effectiveness test showed that the model of the instrument based on the scientific approach is reliable, practice, and effective to be used by English teachers to assess the affective of students. It means that the product of affective instrument has been tested the standards test which is specified by Gall et. al., (2007). The test has been done systematically so that the instrument can be used at different times and by different teachers. Some statistical analyses formulas had been used to prove the reliability, practicality, and effectiveness of this instrument. The Wilcoxon test was used in this study because the data were not distributed normally. Then, the significance score for practicality and effectivity was the same at .042. This Score showed that the composition of practice and effectiveness was the same.

This is also similar to the results of research ever conducted by Givens (2010), where he examined the use of attitude assessment to know the students who like to read and not. By using the attitude assessment, it was known who learners who very love to read and who are the learners who do not love to read. Likewise, with the use of the product of affective instrument, it can be seen who are the learners who have or do not have attitudes such as religious, responsible, self-confident, innovative thinking, honest, independent, discipline, hard-work, logical thinking, critical thinking, love science, creative thinking, curious, respect, polite, emotionally intelligent, democratic and pluralist (Kim \& Kim, 2018). In this part, the English teachers were not only focused on one or two aspects of attitude, but they can be spread the attention of value into some other aspects of attitude. The values that were presented by the students in front of the teachers will be the indicator of successful learning in the English subject (Khan, 2016). As stated in the goal of Education in Indonesia that a school is not only creating a person who has the competency and capability in cognitive but also competence and capable in the affective side.

Affective or character education is also paid much attention from some countries. For example in the United States, Kim, et. al. (2018) reported that character education programs can help the students to educate their behavior. Moreover, if the program is holistic and sets the goal in line with the emphasis of education. Affective or the character education or can give a positive atmosphere to the culture of the school itself. O'Connell as quoted in the California Department of Education (2019), states that every person has a responsibility to prepare students to be good citizens. In line with this condition, the Indonesian government also concerning the performance of affective in an education. The $21^{\text {st }}$ century focuses the affective as the core of life because this is a digital literacy era that force someone to be able to control their thought and action/reaction. Someone who has a good affective will be more peaceful in this life, respect, and responsibility toward something that has been the duty. 
The Jubilee Centre (2017) notes that the schools be able to create the students to become good persons and citizens. Then, the schools must be able also to lead the students to have good lives. The schools that able to do these responsibilities will become 'successful' schools because they can create the 'successful' individual. Because affective or character is a fundamental thing in life. It is the basis for human and social relationships.

Also, based on the research report from Walker, et. al. (2017) in the United Kingdom, some types of affective i.e. leadership, respect, self-control, resilience, motivation, self-confidence, communication skills, and social and emotional skills are needed to make the students succeed after school. The students who have good affective or character will easier to do interact with society in real life and various situation (Oja et. al., 2018). Even though this study assessed eighteen types of attitude such as religious, responsible, self-confident, innovative thinking, honest, independent, discipline, hard-work, logical thinking, critical thinking, love science, creative thinking, curious, respect, polite, emotionally intelligent, democratic and pluralist, but the most concern of fiding showed that honesty, responsible, discipline, and curiosity as the keys of success in learning. Honesty forced the students to self-directed learning. They built an argument in their thought that they must be able to master the material given by the teachers. The responsibility motivates the students to do their duty with discipline (Chari, 2015). Then, curiosity makes the students try to use the process of HOT (Higher Order Thinking) (Sari et. al., 2020). They try to find out about what they learned, how to solve it, and try to implement it in their life.

\section{CONCLUSION}

The primary purpose of this paper was to demonstrate the results of validity, reliability, practicality, and effectivity of the product of affective instruments. This study has shown that there are positive results found from statistical analysis of validity, reliability, practicality, and effectivity for that instrument. These procedures remain essentially the same administration to another. In other words, the product of affective instrument can also be used as an effort to form the affective of students during the English learning process takes place. The product of affective instrument is used as a means of controlling the affective of learners in the EFL classroom. Thus, the development of the product of affective instruments can be seen by English teachers continuously from time to time.

\section{LIMITATION AND STUDY FORWARD}

The development of instruments for affective assessment was limited to the study of validity, reliability, practicality, and effectivity. It is needed to study the implementation of using this instrument to assess the students' affective.

\section{ACKNOWLEDGEMENT}

The authors wish to thank Prof. Safnil Arsyad, M.A., Ph.D., Dr. Zifirdaus Adnan, and Prof. Bambang Kaswanti Purwo. This work was supported in part by a grant from the research of 'Boosting the publication of Indonesian research articles in international journals using a genre-based approach and mentoring program.

\section{REFERENCES}

1. Ali, M. A. K. (2017). English Language Anxiety: Development and Validation of a Brief Measure. International Journal of Psychology and Educational Studies, 4(2), 42-53. https://doi.org/10.17220/ijpes.2017.02.005

2. Anderson, L. W., \& Bourke S. F. (2013). Assessing Affective Characteristics in the Schools (2 ${ }^{\text {nd }}$ ed.). New York: Routledge. https://doi.org/10.4324/9781410605443

3. Atmazaki. (2013). Penilaian Alternatif dalam Pembelajaran Bahasa Indonesia. Padang: UNP Press.

4. Bloom, B. S., Krathwohl, D. R., \& Masia B. B. (1964). Taxonomy of Educational Objectives: The Classification of Educational Goals. Handbook II: Affective Domain. New York: David McKay Company, Inc.

5. Bloom, B. S., Hastings, J. T., \& Madaus, G.F. (1981). Evaluation to Improve Learning. New York: McGrawHill Inc.

6. Gall, M. D., Gall, J. P., \& Borg, W. R. (2007). Educational Research: An Introduction, 8th Edition. New York: Longman. Inc.

7. Branch, R. M. (2009). Instructional Design: The ADDIE Approach. New York: Springer. https://doi.org/10.1007/978-0-387-09506-6

8. Brown, H. D. (2003). Language Assessment: Principle and Classroom Practice. New York: Pearson Education.

9. California Department of Education. (2019). The Role of Character Education in Public Schools. https://www. cde.ca.gov/ls/yd/ce/charactered.asp

10. Chari, S. (2015). The Early Clinical Exposure Experience Motivates First Year MBBS Students: A Study. International Journal of Educational Sciences, 8(02). https://doi.org/10.31901/24566322.2015/08.02.16

11. Faris, M. I. (2012). "Pengembangan Asesmen Diri Siswa (Student Self-Assessment) sebagai Model Penilaian dan Pengembangan Karakter". Konferensi Ilmiah Nasional "Asesmen dan Pembangunan Karakter Bangsa" HEPI UNESA 2012 (68-77).

12. Fazeli, S. H. (2011). The Impact of Personality Traits on the Affective Category of English Language Learning Strategy. LiBRI (Linguistics and Literacy Broad Research and Innovation, (Online), Vol. 2, No. 2. (http://ERIC Journal). 
13. Feist, J. \& Feist G. J. (2006). Theories of Personality ( $6^{\text {th }}$ ed.). New York: McGraw-Hill.

14. Givens, S. M. (2010). Using Affective Assessment to Understand our Students' Identities as Readers (and NonReaders). Inquiry: The Journal of the Virginia Community Colleges 15 (1).

15. Julia, J. \& Supriyadi, T. (2018). The Implementation of Character Education at Senior High School. SHS Web of Conference GC-TALE 2017 (Online), Vol. 42, 00085. https://doi.org/10.1051/shsconf/20184200085

16. Jubilee Centre for Character and Virtues. (2017). A Framework for Character Education in Schools. University of Birmingham.

17. Karto, Suhartono, Susetyo, Noermanzah, Maisarah, I. (2019). The Differences Ability In Writing Descriptive Texts By Using Chain Writing And Conventional Methods. International Journal of Scientific \& Technology Research, 8(10), 2718. http://www.ijstr.org/paper-references.php?ref=IJSTR-1019-24157

18. Keblowska, M. (2012). "The Place of Affect in Second Language Acquisition" dalam Pawlak, Mirostaw (Ed.). Second Language Learning and Teaching: New Perspective on Individual Differences in Language Learning and Teaching (pg. 157-167). New York: Springer. https://doi.org/10.1007/978-3-642-20850-8 10

19. Khan, I. (2016). Positive Attitude and English Language Learning: Psycho-pedagogic Connections. Arab World English Journal, 7(1), 432-444. https://doi.org/10.24093/awej/vol7no1.26

20. Krathwohl, D. R., Bloom, B. S., \& Masia, B. B. (1974). Taxonomy of Educational Objectives: The Classification of Educational Goals. Handbook II: Affective Domain. New York: David McKay Company, Inc.

21. Kemdikbud Republik Indonesia. (2014). Buku Guru Bahasa Inggris: When English Rings a Bell. Jakarta: Kemdikbud.

22. Kemdikbud Direktorat Pembinaan Sekolah Menengah Pertama Direktorat Jenderal Pendidikan Dasar dan Menengah. (2015). Panduan Penilaian untuk Sekolah Menengah Pertama (SMP).

23. Kim, K. Harris, C. J., \& Pham, L. (2018). How Character Education Impacts Teachers. International Journal of Multidisciplinary Perspectives in Higher Educatio, 3 (1), 45-67. https://doi.org/10.32674/jimphe.v3i1.632

24. Kim, D., \& Kim, T.-Y. (2018). The Structural Relationship between Korean High School Students' Resilience, English Learning Motivation, English Class Attitude, and English Learning Achievement. The Modern English Society, 19(1), 120-136. https://doi.org/10.18095/meeso.2018.19.1.11

25. Koc, E. M. (2013). Affective Characteristics and Teaching Skills of English Language Teachers: Comparing Perceptions of Elementary, Secondary and High School Students. Scientific Research, 4 (2). https://doi.org/10.4236/ce.2013.42017

26. Li, L. \& Luo, S. S. (2019). Development and Preliminary Validation of a Foreign Language Aptitude Test for Chinese Learners of Foreign Languages. Language Aptitude, 33-55. https://doi.org/10.4324/9781315122021-3

27. Maisarah, Ira, Zaim, M, Syarif, H, \& Bentri, A. (2018). Designing Affective Instrument based on Scientific Approach for English Language Learning. SHS Web of Conference GC-TALE 2017 (Online), Vol. 42, 00068. https://doi.org/10.1051/shsconf/20184200068

28. Maisarah, Ira, Zaim, M, Syarif, H, \& Bentri, A. (2018). Needs of English Teachers in Designing Instrument of Affective Assessment based on Scientific Approach: A Challenge for Curriculum Development at $21^{\text {st }}$ Century. Advances in Social Science, Education and Humanities Research (ASSEHR), Sixth International Conference on Languages and Arts (ICLA 2017) (Online), Vol 148. https://doi.org/10.2991/icla-17.2018.55

29. Markle, R. dan O'Banion, T. (2014). Assessing Affective Factors to Improve Retention and Completion. Learning Abstract, (Online), 17(11): 1-16. https://www.ets.org/s/.../pdf/learning_abstracts_markle_obanion.pdf

30. McCoach, D. B., Gable, R. K., \& Madura, J. P. (2013). Instrument Development in the Affective Domain: School and Corporate Application ( $3^{\text {rd }}$ ed.). New York: Springer. https://doi.org/10.1007/978-1-4614-7135-6

31. Oja, B. D., Clopton, A. W., \& Hazzaa, R. N. (2018). Assessing Student Affective Commitment and Adjustment: The Function of Social Capital. College Student Affairs Journal, 36(2), 48-62. https://doi.org/10.1353/csj.2018.0015

32. Palk, K. (2018). Middle School Teachers Attitudes Towards the Need for Student Feedback and Attitudes Towards the Impact of Feedback on Teachers Professional Development. INTED2018 Proceedings. https://doi.org/10.21125/inted.2018.0653

33. Sari, M.H., Susetyo, Noermanzah, Wardhana, D.E.C., Kusumaningsih, D. (2020). Understanding the Level of Students' Reading Comprehension Ability. Universal Journal of Educational Research, 8(5), 1848 - 1855. https://doi.org/10.13189/ujer.2020.080521

34. Muttaqin, M. F., Raharjo, T. J., \& Masturi. (2018). The Implementation Main Values of Character Education of Reinforcement in Elementary School. Journal of Primary Education, 7 (1), 103-112.

35. Nitko, A. J. (2001). Educational Assessment of Students ( $3^{\text {rd }}$ ed.). New Jersey: Merrill Prentice Hall.

36. Noermanzah \& Friantary, H. (2019). Development of Competency-Based Poetry Learning Materials for Class $\mathrm{X}$ High Schools. International Journal of Recent Technology and Engineering, 8(4), 6631. https://doi.org/10.35940/ijrte.D8855.118419

37. Nufus, S. H., Gani, A., \& Suhendrayatna. (2017). Pengembangan Instrument Penilaian Sikap berbasis Kurikulum 2013 pada Pembelajaran Kimia SMA. Jurnal Pendidikan Sains Indonesia, 5 (1), http://jurnal.unsyiah.ac.id/jpsi 
38. Octova, A., Bentri, A., Putra, A., Hidayati, A., \& Rahmi, U. (2014). Implementasi Kurikulum 2013 di Sumatera Barat. Jurnal Penelitian Pendidik, 5 (1). http://ejournal.unp.ac.id//index.php/penelitianpendidikan/a rticle/view/4133

39. Pham, J. (2015). A Student's Perspective on Assessment and the Affective Domain. American Journal of Pharmaceutical Education, 79(8), 125. https://doi.org/10.5688/ajpe798125

40. Piasecka, L. (2013). "What Does It Feel Like to Use English? Empirical Evidence from EFL Students" dalam Piechurska-Kuciel, Ewa \& Szymanska-Czaplak, Elzbieta (Eds.). Second Language Learning and Teaching: Language in Cognition and Affect (pg. 219-237). New York: Springer. https://doi.org/10.1007/978-3-64235305-5 13

41. Rani, Rusilowati, A. \& Ellianawati. (2010). Penerapan Peer-Assessment dalam Menilai Sikap Ilmiah Siswa pada Mata Pelajaran Fisika SMA Kelas X. Seminar Nasional Fisika (Online), Universitas Negeri Semarang 2 Oktober 2010. https://www.researchgate.net/publication/283244370

42. Riduwan. (2015). Metode dan Teknik Menyusun Tesis. Bandung: Alfabeta Bandung.

43. Rimland, E. (2013). Assessing Affective Learning Using A Students Response System. Libraries and the Academy Journal, 13 (4). https://doi.org/10.1353/pla.2013.0037

44. Syarif, H. (2014). "The Value of Language Politeness in Education". Proceeding of the Third International Seminar on Languages and Arts (Online), UNP, October 17-18, 2014. (http: //ejournal.unp.ac.id/index .php/isla/article/view/5302/418)

45. Sudirman. (2019). The 21st-Century Teacher: Teacher's Competence Within the Character Education Framework Towards A Cultural-Oriented Development and Promoting Tolerance. International Education Studies, 12 (8), 21-25. https://doi.org/10.5539/ies.v12n8p21

46. Sugiyono. (2017). Metode Penelitian Kuantitatif, Kualitatif dan R\&D. Bandung: Alfabeta.

47. Turi, J., Sorooshian, S., Binti Mahmud, F., \& Javed, Y. (2018). The Cognitive, Behavioral and Social Prospectives of Organizational Learning through Information System. Malaysian Online Journal of Educational Management, 6(3), 71. https://doi.org/10.22452/mojem.vol6no3.4

48. Undang-Undang Number 20 Tahun 2003 about Sistem Pendidikan Nasional.

49. Walker, M. Sims, D. \& Kettlewell, K. (2017). Leading Character Education in Schools. Berkshire: National Foundation for Educational Research.

50. Wicaksono, T.P., Muhardjito, \& Harsiati, T. (2016). Pengembangan Penilaian Sikap dengan Teknik Observasi, Self-Assessment, dan Peer-Assessment pada Pembelajaran tematik Kelas V SD Arjowinangun 02 Malang. Jurnal Pendidikan: Teori, Penelitian, dan Pengembangan, 1 (1), http://journal.um.ac.id/index. php/jptpp/article/view/ 5214

51. Zaim, M. (2017). Implementing Scientific Approach to Teach English at Senior High School in Indonesia. Asian Social Science, 13 (2). https://doi.org/10.5539/ass.v13n2p33 